$9-1998$

\title{
Special Conference Issue (1998)
}

Follow this and additional works at: http://digitalcommons.cedarville.edu/ ohio_independent_baptist

Part of the Christian Denominations and Sects Commons, and the Organizational Communication Commons

\section{Recommended Citation}

"Special Conference Issue (1998)" (1998). The Ohio Independent Baptist. 261.

http://digitalcommons.cedarville.edu/ohio_independent_baptist/261

This Newsletter is brought to you for free and open access by DigitalCommons@Cedarville, a service of the Centennial Library. It has been accepted for inclusion in The Ohio Independent Baptist by an authorized administrator of DigitalCommons@Cedarville. For more information, please contact digitalcommons@cedarville.edu. 


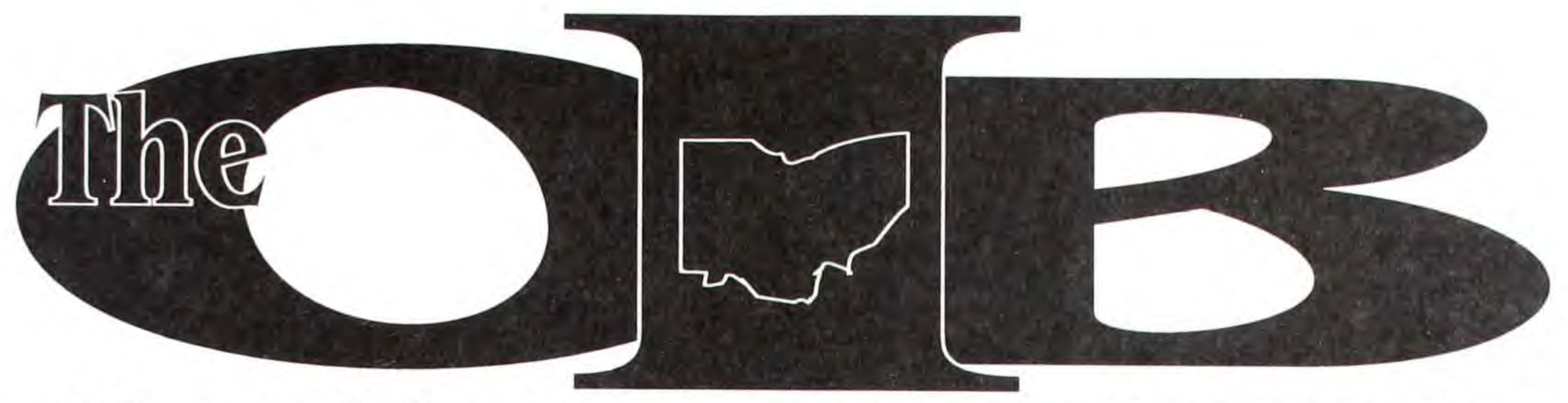

The Olhio lindependent Baptist

The Newsletter of the Ohio Association of Regular Baptist Churches

Ofio Association of Regular Baptist Churches 71st Annual Conference

\section{"HAVE FAITH IN GOD."}

FOR ASSUREDLY, I SAY TO YOU, WHOSOEVER SAYS TO THIS MOUNTAIN, 'BE CAST INTOTHE SEA,'AND DOES NOT DOUBT IN HIS HEART, BUT BELIEVES THAT THOSE THINGS HE SAYS WILL COME TO PASS, HE WILL HAVE WHATEVER HE SAYS.

Mark 11:22,23

\section{October 26-27, 1998}

New Milford Baptist Church 4808 East Tallmadge Road Rootstown, OH 44272-0208

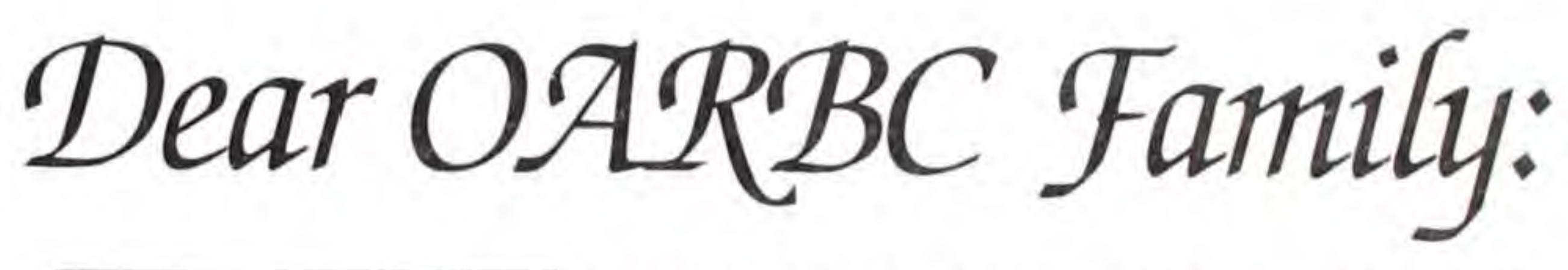

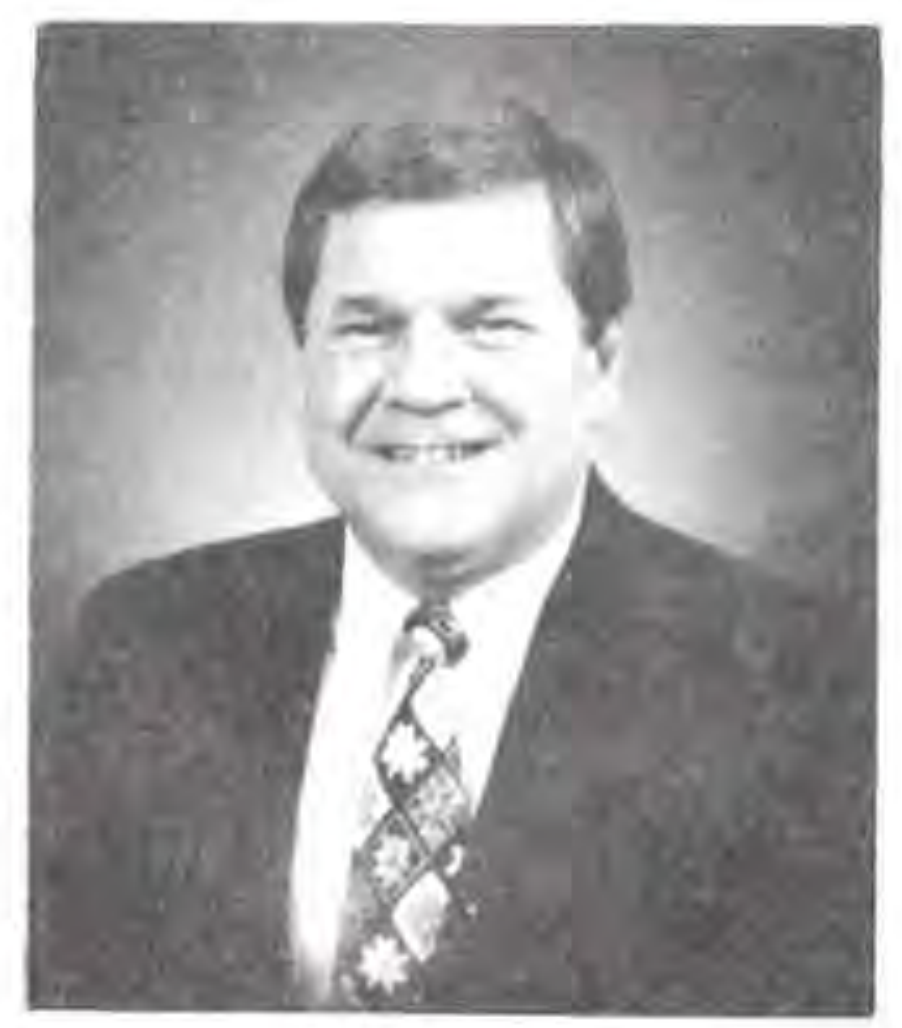

Two great days have been planned by our Council of 12 , with dynamic preaching by Dr. Ernest Pickering and Dr. David Warren. Arrangements have been made to provide for your needs both days.

These are perilous times in our country. We need each other. Our fellowship is not complete without you. Let's "Have Faith in God." that He might expand our vision.

We look forward to being your hosts. Please join us here in northeastern Ohio, just 16 miles east of Akron on I-76, as we expect God's refreshing and seek to encourage one another for His glory.

Serving Jesus 'til He comes,

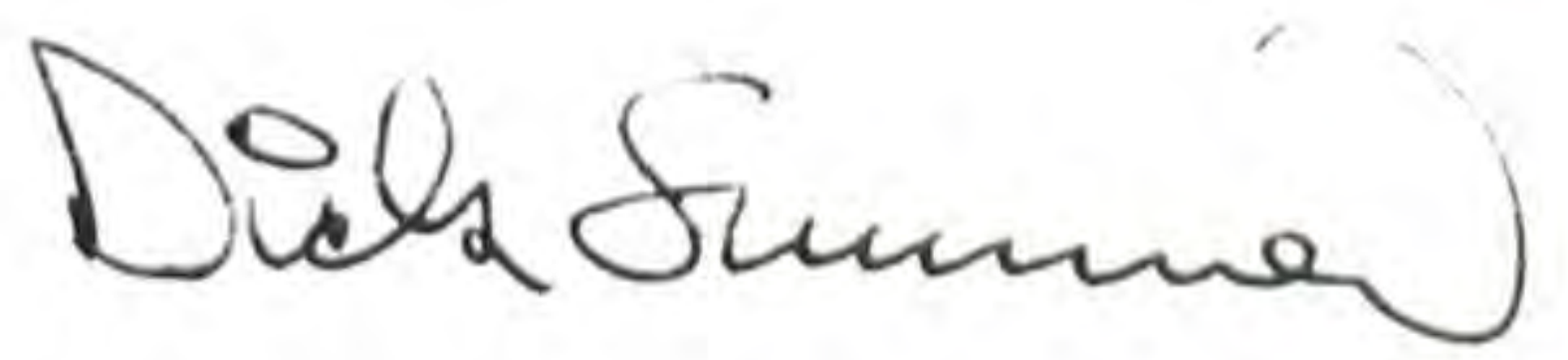

Dick Sumner

Senior Pastor

\section{Keeping You Informed}

November 5 is the deadline for the next regular edition of the OIB. Please submit your church news and articles by that date.

Have questions about the conference? Just call the New Milford Baptist Church at 330-325-7174. 


\section{Conference Schedule}

\section{Monday, October 26}

\section{MORNING SESSION}

9:00 a.m. Registration/Prayer

10:00 a.m. Association Hour

11:00 a $\mathrm{m}$. Bible Hour - Singing \& Special Music

Message: Dr. David Warren

"Trust Him for the Stuff of Life" (Matthew 8:19-34)

\section{AFTERNOON SESSION}

2:00 p.m. Men \& Ministry

Dr. Ernest Pickering (Auditorium)

Women's Session

Mrs. Merle Brock (Fellowship Hall)

3:15 p.m. Men's Session

Meet the State Rep (Auditorium)

Women's Session

Mrs. Pat Warren (Fellowship Hall)

5:00 p.m. Newcomers' Banquet (Northeast Ohio College of Medicine)

\section{EVENING SESSION}

7:00 p.m. Bible Hour - Singing \& Special Music

Introduction of New Pastors/Offering

Message: Dr. David Warren

"Trust Him in the Storms of Life" (Matthew 8:23-27)

\section{Tuesday, October 27}

\section{MORNING SESSION}

8:00 a.m. Continental Breakfast, Provided by Host Church

8:30 a.m. Prayer Time - led by Dr. Warren

9:00 a.m. Bible Hour - Singing \& Special Music Message: Dr. Ernest Pickering

10:00 a.m. Association Hour

11:00 a.m. Bible Hour - Singing \& Special Music

Message: Dr. David Warren

"Trust Him for Your Steps in Life" (Matthew 14:22-33)

\section{AFTERNOON SESSION}

\section{2:00 p.m. Ohio Women's Missionary Union (Auditorium)}

Conference Workshops

CE/Youth Internships: Mr. Tom Hutchison (Senior High Room)

Cult Awareness: Rev. Dale Byers (Junior Room)

Writing: Mrs. Sandy Harner (Disciples Classroom)

Preaching: Dr. Ernest Pickering (Fellowship Hall)

3:15 p.m. Conference Workshops

A Second Look at Sports: Dwight Allen (Junior Room)

Being the Second Man: Dr. Brad Quick/Church Staff (Senior High Room)

Leadership: Dr. Duane Wood (Disciples Classroom)

Planning for the Church: Dr. Martin Clark (Fellowship Hall)

\section{EVENING SESSION}

7:00 p.m.

Closing Session - Singing \& Special Music

Introduction of New Council Officers

Message: Dr. David Warren

"Trust Him for Your Stands in Llfe" (Matthew 18:5-12) 


\section{From Our Heart To Yours}

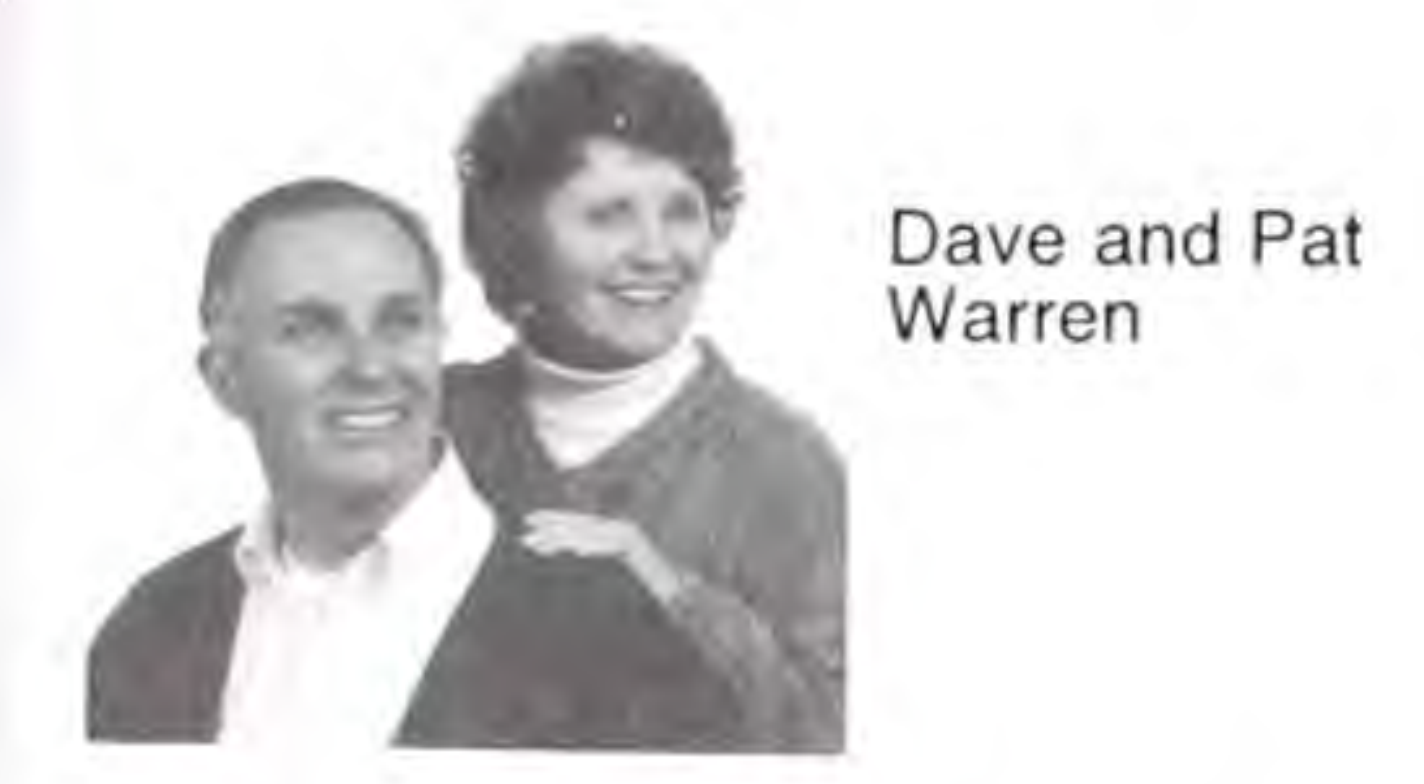

$\mathrm{O}$ $\mathrm{n}$ four different occasions in Matthew's Gospel our Lord addressed His hearers as "O ye of little faith." The title served as both a mild rebuke and a challenge to growth. He was not being harsh with them but was definitely goading them on to new heights or at least to some new arenas in which their faith could develop.

Like those disciples of old we all could use fresh encouragement to grow in our faith. Our spirits resonate with theirs when they said, "Lord, increase our faith." Whether our concerns center on the mundane, day-to-day concerns of life, or on the larger issues of crises and decisions, we all could use a healthy shot-in-the-arm when it comes to faith.

And that is what this Rootstown conference is all about! I invite you to come, to bring the people from our churches with you, to inform our congregations as to this theme, to pray for the renewing and refreshing that we all need from heaven.

Did I say "the people?" Yes, definitely! Ours is an association of churches, not just pastors and leaders. Encourage your people to come; make them aware of the dates, times and places. We all need the lift, the warmth, and the strength that comes from sharing together, from seeing one another, from simply being together! Fellowship around the Word will indeed strengthen our faith. Hope to see you there!

\section{Dear Sisters In Christ,}

M y pastor, Bill Abernathy, Jr., recently conducted a study of the book of Acts. The title of his message for Acts 28:11-24 was, "Don't Forget the Necessities." At the top of our sermon outline notes he wrote the following: "Sometimes in the hustle and bustle of life we can forget something important. Paul's final leg of his journey to Rome reminds us of two necessities we must not forget." He then listed those two necessities: 1) Fellowship with other believers and 2) Witness to unbelievers.

As we looked at Acts 28:14,15 that Sunday, Pastor Bill reminded us that fellowship with other believers ought to be a priority for us because it is of great benefit to us. Those verses say the brothers traveled to meet Paul as he approached Rome and..."Paul thanked God and was encouraged." Isn't that great?

And isn't it still true today? Isn't it true of our OWMU meetings? This October we will take the time to travel to Rootstown, and when we see each other, we will give thanks to God and be encouraged! Then God will use us to encourage our missionary friends around the world.

I'm sure some of "the brothers" had to rearrange busy schedules to travel out to the Forum of Appius and Three Taverns to meet Paul. But I'm also sure they were glad they did. It was a priority to them. 1 hope coming to Rootstown will be a priority for you. Help make it so by singing the following words to the tune of "When the Roll Is Called Up Yonder."

"When my sisters meet in Rootstown to fellowship and pray

And they focus on God's servants everywhere.

When they join their hearts so lovingly on that October day, And the Lord sends down His blessings I'll be there.

When my sis-ters meet in Rootstown, When my sis-ters meet in Rootstown, When my sis-ters meet in Rootstown, When my sis-ters meet in Rootstown I'LL BE THERE."

\section{- Praying you will be, Sue Miller}

\section{Conference Program To Include Teens}

$T_{\mathrm{p}}^{\text {he }}$ hree of this year's Talents For Christ participants will be on the program for the OARBC conference at Rootstown. They are: Bethanne Starett (Visualized Bible Teaching, Camden): Natalie Nicholl (Woodwinds, Piqua); and Melissa Walsh (Female Voice. Toledo). We look forward to their involvement in the conference.
OARBC CONFERENCE

\section{MOTEL INFORMATION}

All motels listed are at Exit 33,

1-76, at Route 43, Kent, $\mathrm{OH}$

Please state that you are attending the OARBC State Conference at the New. Milford Baptist Church in Rootstown.

\section{Alden Inn}

4386 State Route 43

Brimfield, $\mathrm{OH} 44240$

330-678-9927

indoor pool \& jacuzzi

free coffee, 2 double beds

new motel

$\$ 39.95$ plus tax

(\$44.95 plus tax weekends)

\section{Days Inn}

4422 Edson Road

Kent, $\mathrm{OH} 44240$

330-677-9400

complimentary continental breakfast outdoor pool, quiet, away from highway

$\$ 38$ plus tax (state tax exempt w/tax exempt form \& number, but local $6 \%$ tax is nonexempt) Contact Daniel D. Smith, manager

\section{Hampton Inn}

4406 State Route 43

Kent, OH 44240

330-673-8555, FAX673-4455

80 rooms, in-room coffee maker

indoor pool, new motel

Call for rates

\section{Holiday Inn}

4363 State Route 43

Kent, $\mathrm{OH} 44240$

330-678-0101, FAX677-5001

154 rooms, full-service restaurant,

fitness room, in-room coffee maker

game room, cable TV

$\$ 59$ plus tax (special rate)

Contact Emily Roberts

\section{Super 8}

4380 Edson Road

Kent, $\mathrm{OH} 44240$

330-678-8817

61 rooms, free local calls

complimentary morning rolls \& coffee

$\$ 30$ plus tax (special rate)

Contact Carole Trexler, manager

Limited free housing is available through New Milford Baptist Church. Contact Beth in the church office at 330-325-2620. 


\section{The OARBC: Who Needs It?}

$\mathrm{W}$ ho needs the OARBC? To some folk that question may seem very irreverent. No one should even suggest the OARBC is no longer necessary. "It has been around for years, it is the way we have 'done church,' and there is no good reason to doubt its validity." some would assert.

The truth is, however, that many busy pastors and their people may have asked that question in the privacy of their minds if not aloud in the presence of others. From a pragmatic standpoint, who needs another meeting to attend or another responsibility to fulfill? Pastor and people alike have "more on their plate" now than they know what to do with. How can they be expected to show interest in activities and people beyond the four walls of their own churches? There's no time! Our own busyness makes it easy to stay away from broader groupings. Maybe we would all be better off with one less engagement in our schedules.

Others could respond to the question with the thought, "I don't think it is an irreverent question; to me it is a very relevant question. It is relevant, especially in the light of the current philosophical and theological mood in which we live."

And just what does that mean?

For starters, we live in a postmodern world. Many people no longer believe in a logical explanation for the universe or for any given way of life. Scientific methodology has been scrapped as out-dated and logic no longer holds sway over life as it once did. Objectivity has yielded to subjective impression and each person is free to determine the meaning of words and events for himself. No longer can we analyze reality; we can experience it but not explain it. The cause/effect way of looking at things no longer counts. At least it is not as important as it used to be. As a result no one can pass judgment on another's approach to life as that is his own private business. Tolerance is in, absolutism is out. In a post-modern world everything is relative and highly individualized.

We also live in a post-denominational world. What that means in simple terms is that many people no longer wish to be identified with any religious tag. The mood of our day is to emphasize commonality rather than to recognize distinctiveness. Group titles speak to many people today about carnality and stubbornness. Many feel that denominations came into existence only as a result of people's stubborn defense of private agendas, rather than legitimate differences of Bible interpretation. To them, divided Christianity is an ugly scene caused by personality cults and their resultant squabbles. Some suggest the best thing that could happen is for these "walls to come down" and for true unity to prevail. They say that not until that happens can we expect the blessing of God to become evident and many to be swept into the kingdom because they can observe our true unity as one people of God. Combative rhetoric is out; love is in. Group loyalty is out; individual comfort zones are in; interdependence is out; independence is in. Community is out; autonomy is in.

In the resultant milieu, denominations are shrinking, church membership is in decline, and some churches are softpedaling their historic titles. Christians are scrambling to show a united front to a watching world, while at the same time trying to do so from an individualistic standpoint. Denominations are "hanging on for dear life" until this tide of individualism washes past them and the need for "community" is once again recognized.

So it is a relevant question in the light of our present situation. Who now needs the OARBC? Is it an asset or a liability? Is it time to scuttle it, to deconstruct it? Is there any biblical basis for its existence? Whether one approaches the question from a pragmatic or from a philosophical point of view, the question is valid and deserves a good answer.

\section{The Value of Friendship}

A very wise man moves us toward a good answer in his discussion of the value of friendship. Do you realize that the OARBC is precisely that? A friendship. We are people who not only hold to the same doctrinal tenets but who also like each other. We are friends at the churchly level. What binds us together is not some external form or even a longstanding tradition. A warm friendship exists among us and we do enjoy it. Listen to what Solomon said about friendship:

"Two are better than one, because they have a good reward for their labor For if they fall, one will lift up his companion. But woe to him who is alone when he falls, for he has no one to help him up. Again, if two lie down together, they will keep warm; but how can one be warm alone? Though one may be overpowered by another, two can withstand him. And a threefold cord is not quickly broken" (Ecclesiastes 4: 9-12),

What Solomon says here about the value of a friend can easily be applied to the role of the OARBC in the work of the churches. In the analogy that he draws he employs three figures of speech to illustrate the value of a good friendship. First, a friend provides a lift for our downness." If they fall, one will lift up his companion." We do get down from time to time-all of us do. Not everything goes smoothly or according to our wishes. The problems with which we struggle are real and can wear us down. Often we find ourselves alone with little emotional support as we face big-time challenges. At such times we need a friend to listen and to lift us. And we have a friend-in fact we have many of them-in the OARBC.

Second, a friend provides warmth for our coldness. "If two lie down together, they will keep warm." Our own spiritual fervor can cool off and we can end up simply "going through the motions" of ministry while feeling little joy and gaining little satisfaction from our work At times people can be very disappointing if not downright mean and harsh. Our enthusiasm can get cold water thrown all over it and no one seems to be willing to try anything new or innovative. Maintaining the status quo seems to 
New Milford Baptist Church

4808 E. Tallmadge Rd.

Rootstown, Ohio

invites you to the Fall Meeting

Ohio Women's Missionary Union

Tuesday, October 27

2:00 p.m.

\section{Theme:}

\section{"She Hath Done What She Could" Speaker: \\ Mrs. Nancy Wolf}

Nancy and her husband, Tom, are newly appointed ABWE candidates to South Africa. They are members of Memorial Baptist Church in Columbus. Nancy is currently serving as president of our West Moriah Area Fellowship.

\section{Special Features: \\ Two Visits}

Visit \#1 We will "visit" via video with Mrs. Rose Archambault. She and her husband, Keith, serve with Baptist Missionary Builders. Johnstown Independent Baptist Church is their home church.

Visit \#2 A well-known "columnist" will come by for a visit. She asked her identity remain secret, so that's all the information you'll squeak out of me!

\section{Who Needs It?}

be the deadly agenda that gradually cools our warm spirits and kicks the life out of our joy. At such times we need a friend to come alongside and pray with us, and to refresh our spirit. And we have a friend - in fact we have many of them-in the OARBC.

Third, a friend provides strength for our weakness. "Though one may be overpowered by another, two can withstand him." Sometimes we actually bump up against situations for which no amount of schooling could ever prepare us. Complex interpersonal problems with even more complex ramifications challenge our thinking. How can we apply the teaching of the Scripture with a consistency and a clarity that seemed to characterize simpler times? There are times when we get beyond our level of expertise or at least out of our comfort zones. We feel that we could be blown away by some of the complex opponents we face. At such times we need a friend OARBC

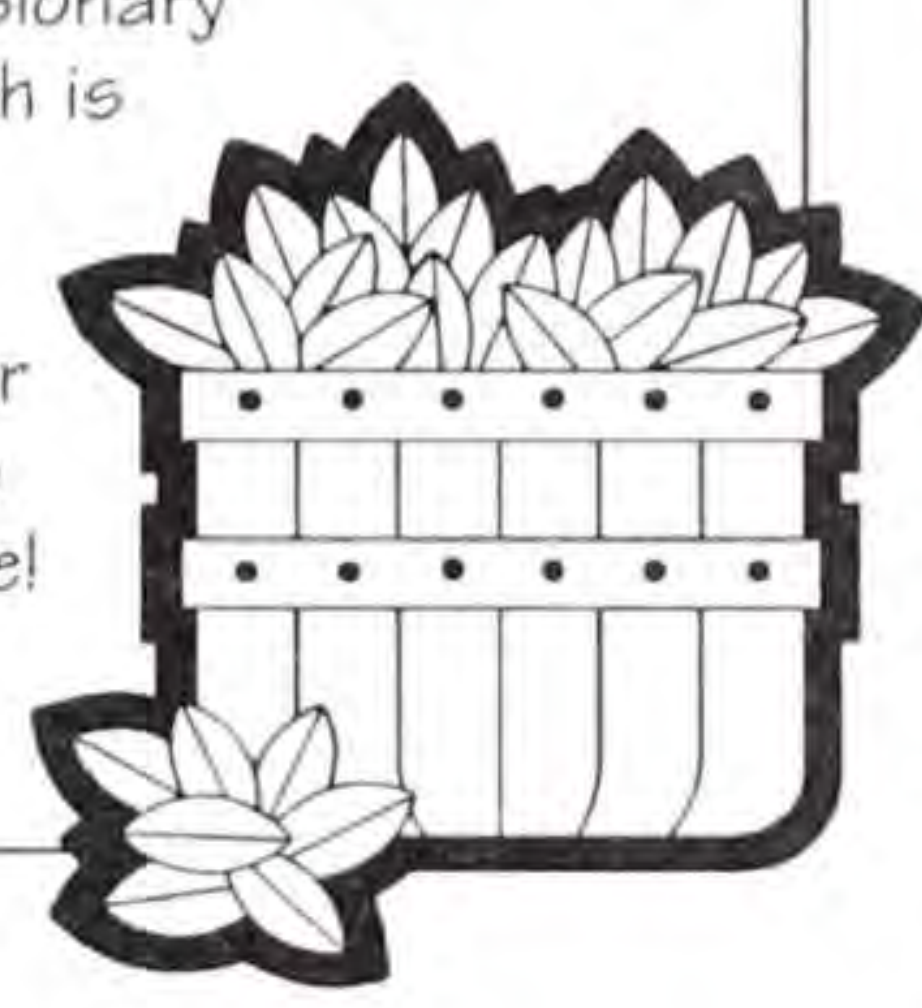

\section{Fellowship at your fingertips!}

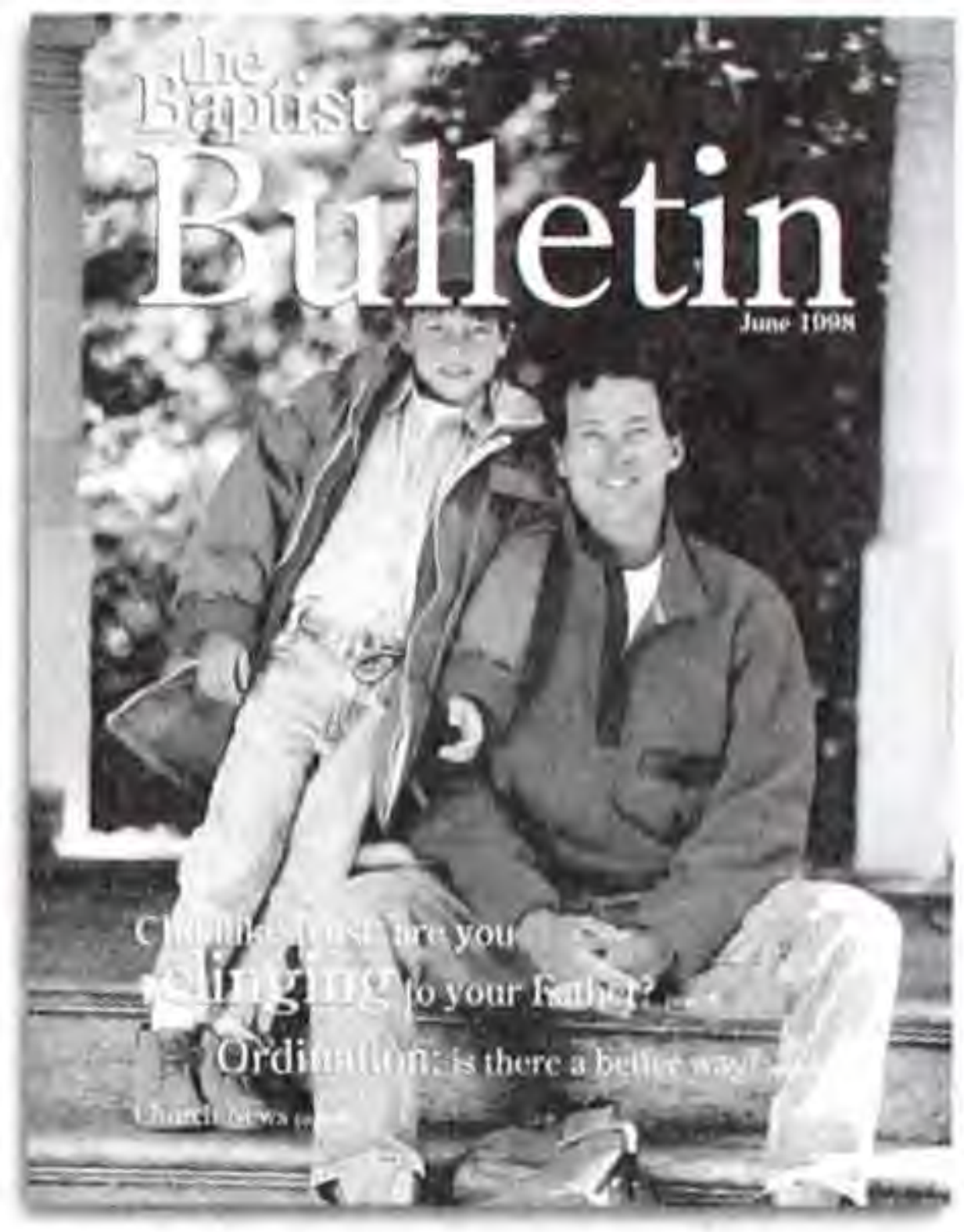

Subscribe Today!

1.888.588.1600

Web site: www,garbc org E-mail: baptistbulletin $($ garbc.org

General Association of Regular Baptist Churches GARBC

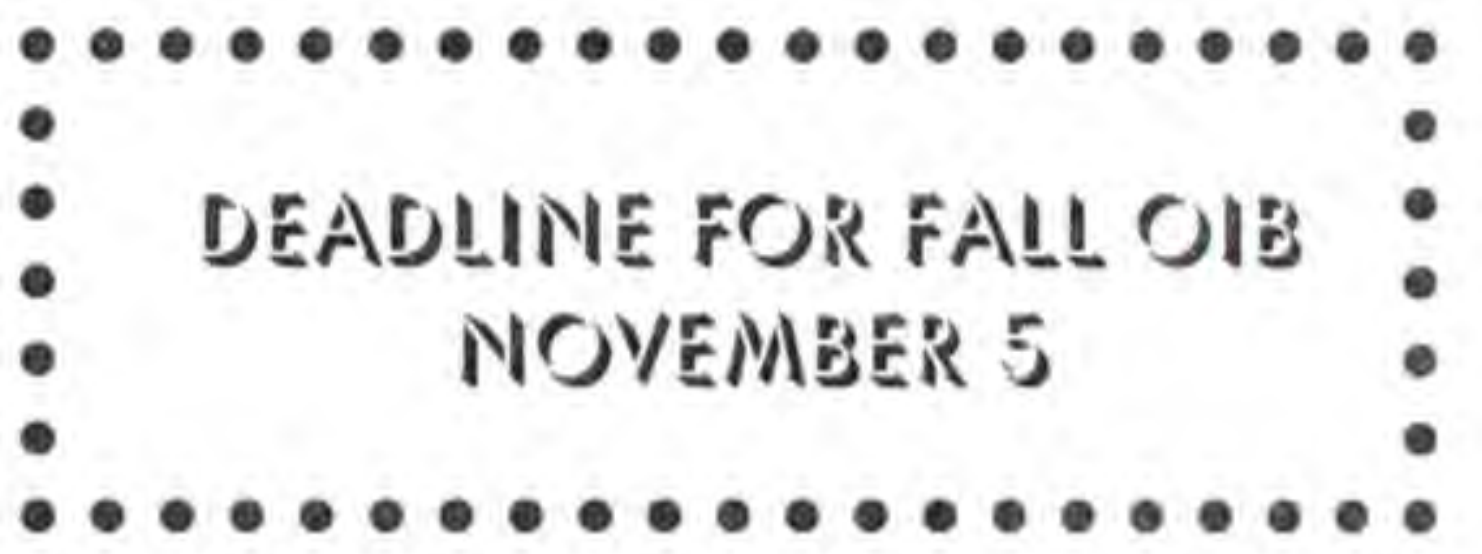

Ohio Independent Baptist

is a publication of the

Ohio Association of

Regular Baptist Churches

through the options, to share his or her experience in dealing with similar situations. And we have a friend - in fact we have many of them-in the

Solomon states categorically that "two are better than one" and "a threefold cord is not quickly broken." There is strength in numbers and wisdom in a multitude of counselors. Who needs the OARBC? Whoever needs a friend in the work of the Lord needs such an Association. Whoever understands that he or she is not the Lone Ranger but is rather a Spiderman on a web of interpersonal relationships in the Body of Christ and in the local church. Whoever on occasion needs a lift, some warmth, or some strength has a friend-in fact, many of them-in the OARBC. "And a threefold cord is not quickly broken."

\section{Editor}

State Representative David Warten

\section{Managing Editor}

Linda Thomas

Proofreader

Deborah Bissett

Technical Assistance

Register Graphics

Randolph, New York

Please direct all comments, correspondence, and news to Ohio Independent Baptist P.O. Box 293058

Kettering, $\mathrm{OH} 45429$

The OIB is published five times per year by the Ohio Association of Regular Baptist Churches, 327 East Drive, Dayton, $\mathrm{OH} 45419$ Subscriptions are \$4 (\$8 foreign) per year
937-294-0293 


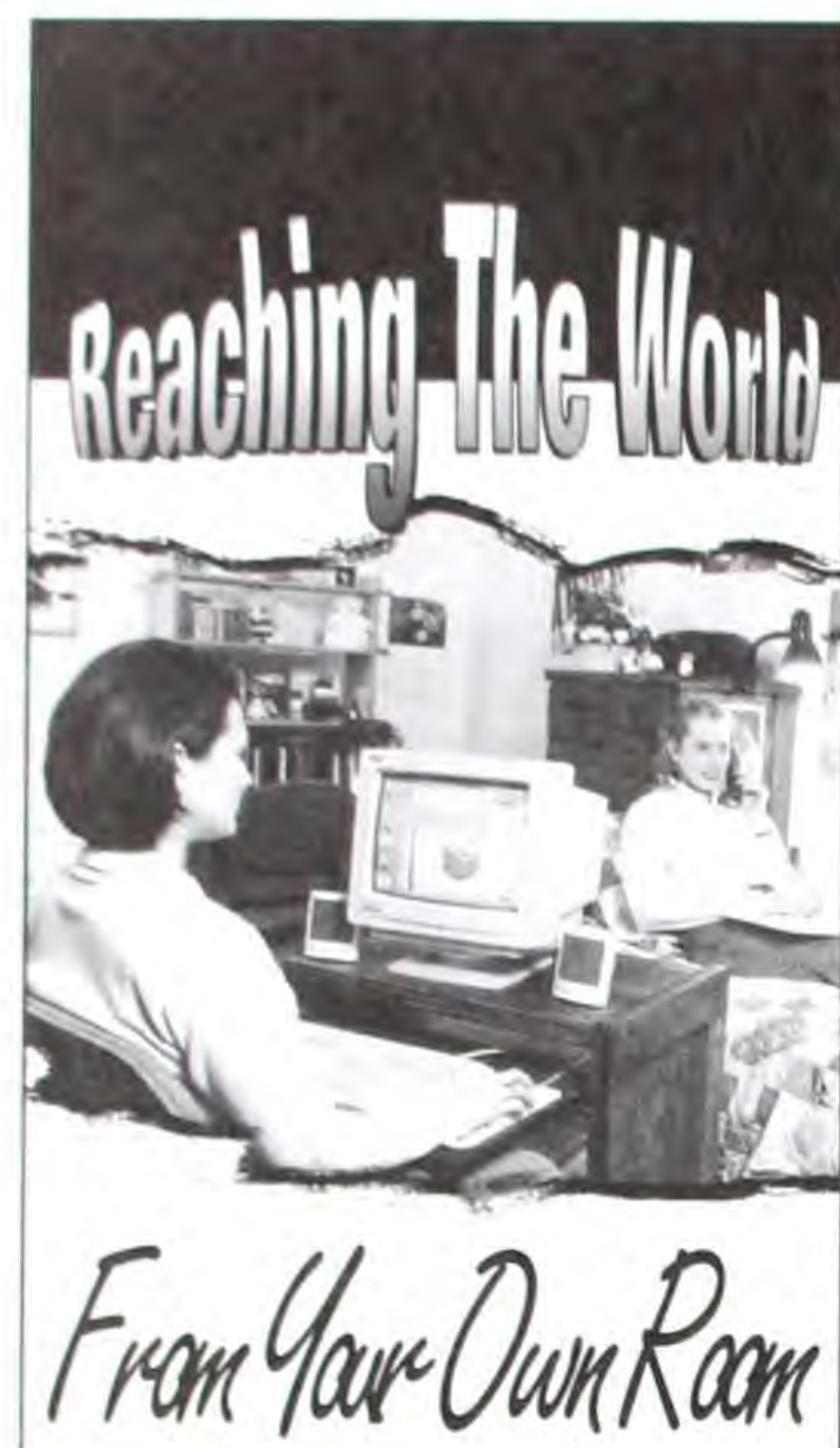

hroughout history, the gospel has been communicated in

many forms. Hand-

written scrolls, printed pages, and modern airwaves have all been used as media to spread the gospel. At Cedarville College, students use the medium of their generation to reach the world for Christ. From every residence hall room on campus, students use the newest computer technology to access data worldwide, order library materials, read the latest magazine or journal, correspond with family and friends, and spread the gospel-24 hours a day, 7 days a week. All this and more is available at no extra cost through Cedarville's awardwinning computer network.

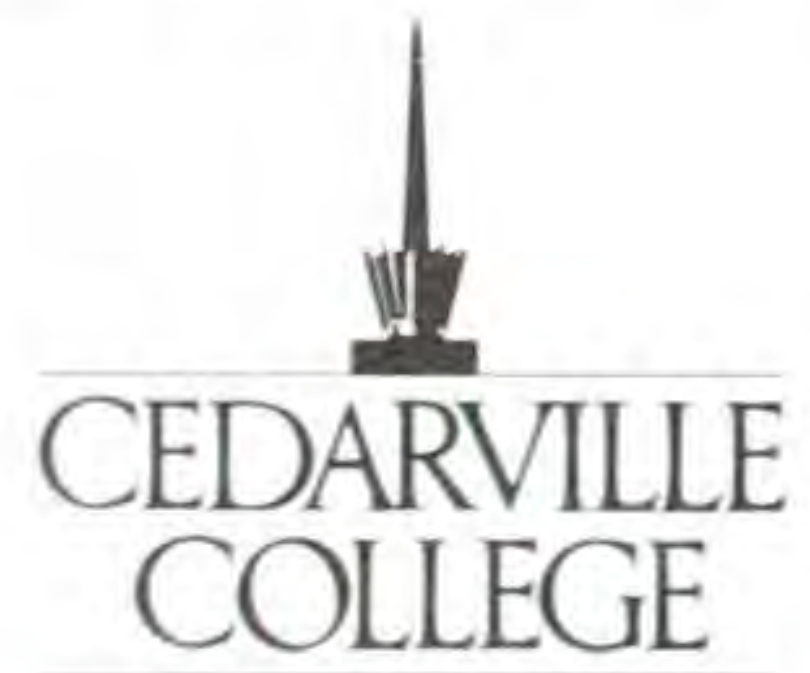

Gall Admissions

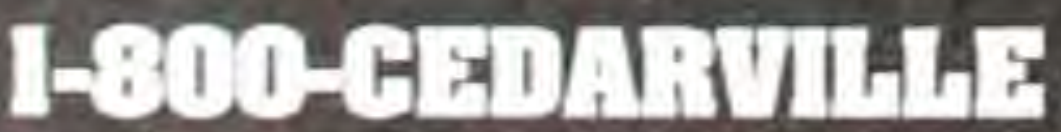

or visit wnucedarvilla.edu

\section{Across the State}

\section{Lightning Strikes Oberlin Church}

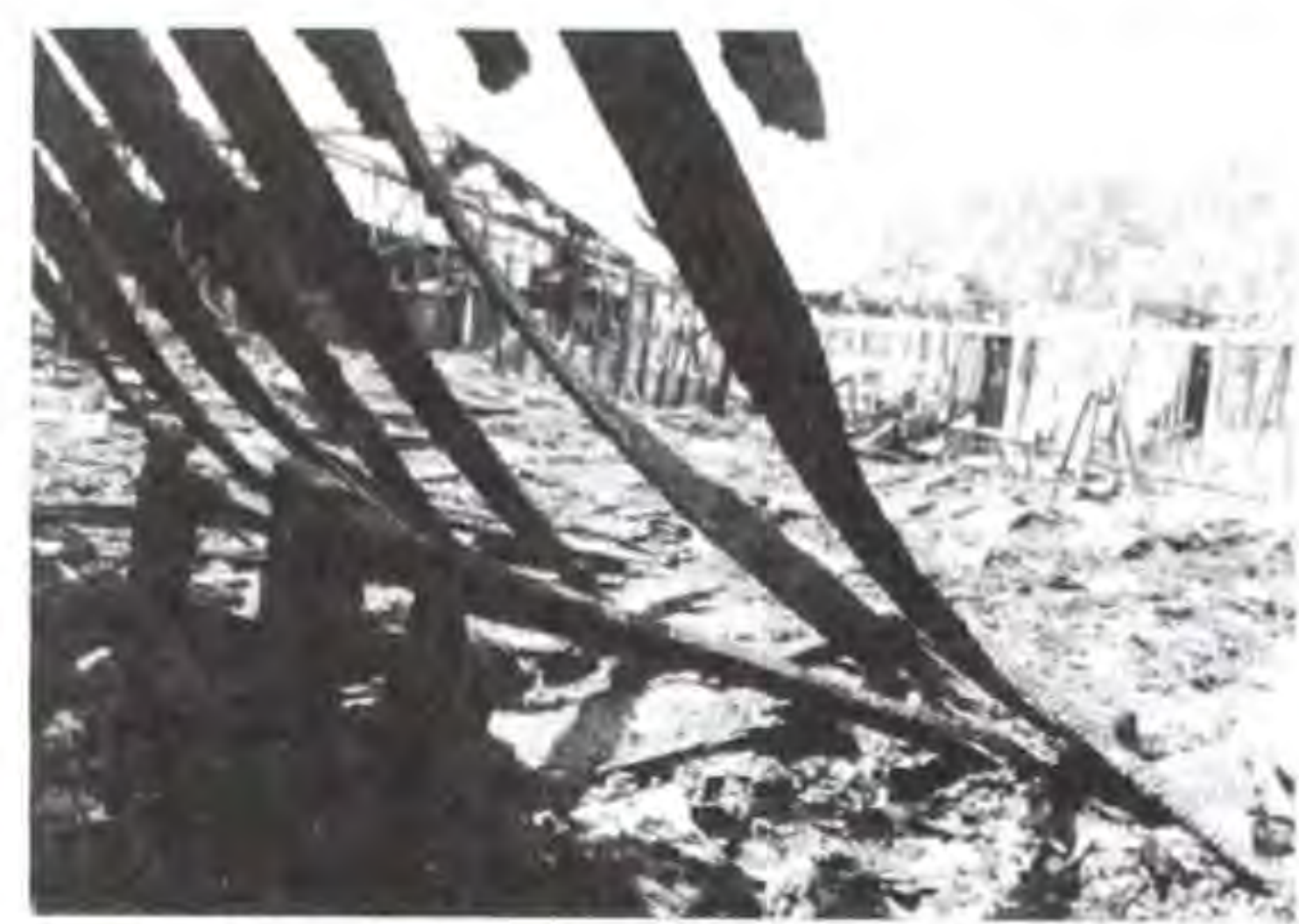

Remains of worship center

( n Tuesday, July 21, lightning struck the Camden Baptist Church of Oberlin, Ohio, destroying two of their three structures. But Pastor Cal Searles notes that, in the midst of their grief, the congregation began to see the hand of God at work in hearts. One evidence of God's movement among the people is the provision of 20 acres of land to erect a new facility. "We have been praying for years for more space," says Searles. "We were a growing church in a small, land-locked facility. After the Lord 'took' the majority of our facility, He answered our prayer in a dramatic way when a near-by landowner graciously gave us 20 beautiful acres." Searles notes that the congregation is facing a huge job. "In a sense it's like a church-plant." he says. "We lost everything - pews, hymnals, office equipment-everything. But we have a lot of hard workers here." Writing to the congregation he said, "We are deeply humbled and in awe of God's power, plans and blessings. The theology we believe in and the promises we claim are being demonstrated and fulfilled for all to see. Surely, He is worthy of worship. Surely, our faith in God-His timing,

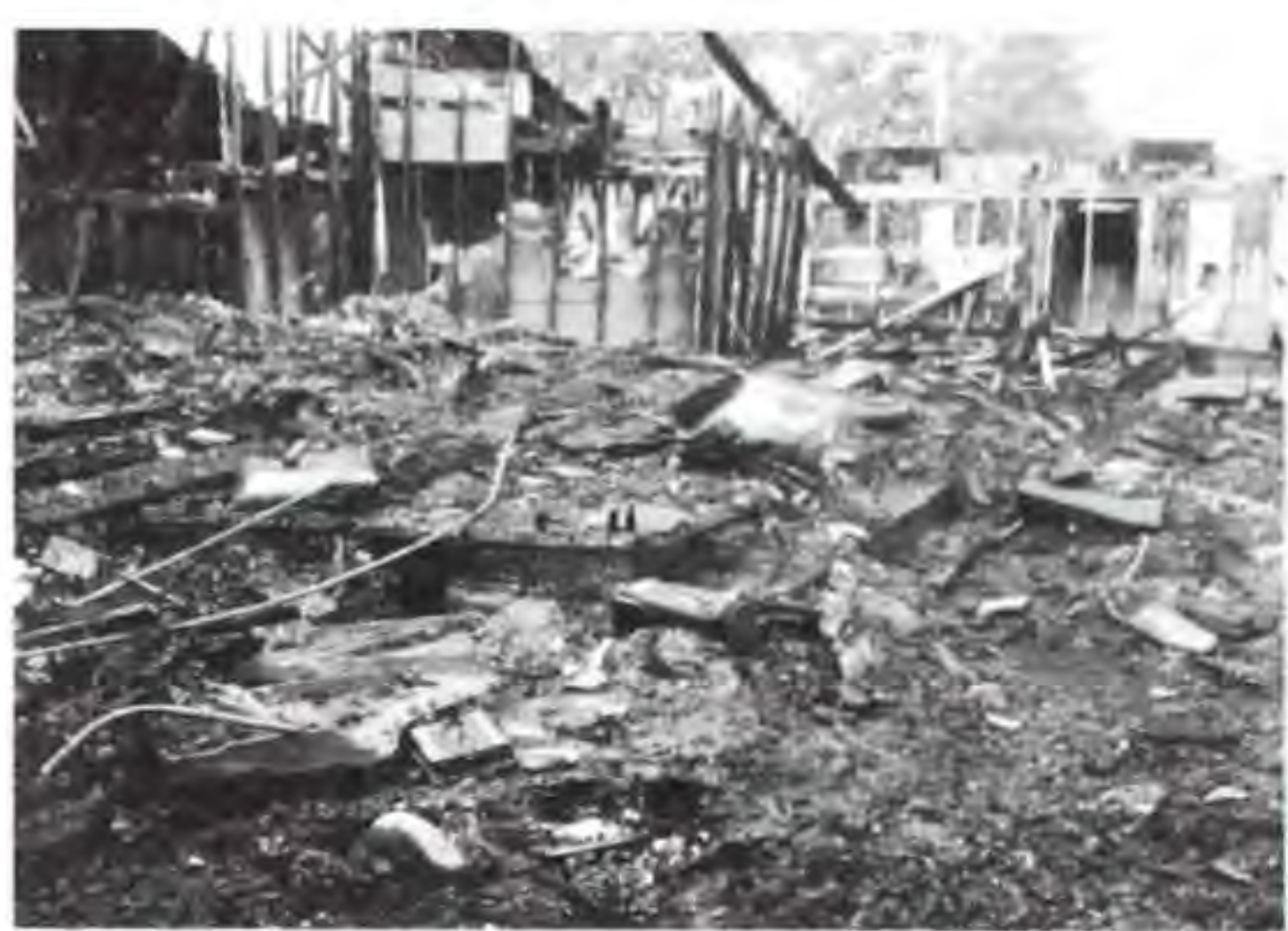

Communion table, pulpit \& platform

His goodness, His plans-has been significantly strengthened. God still does work in great and mighty ways."

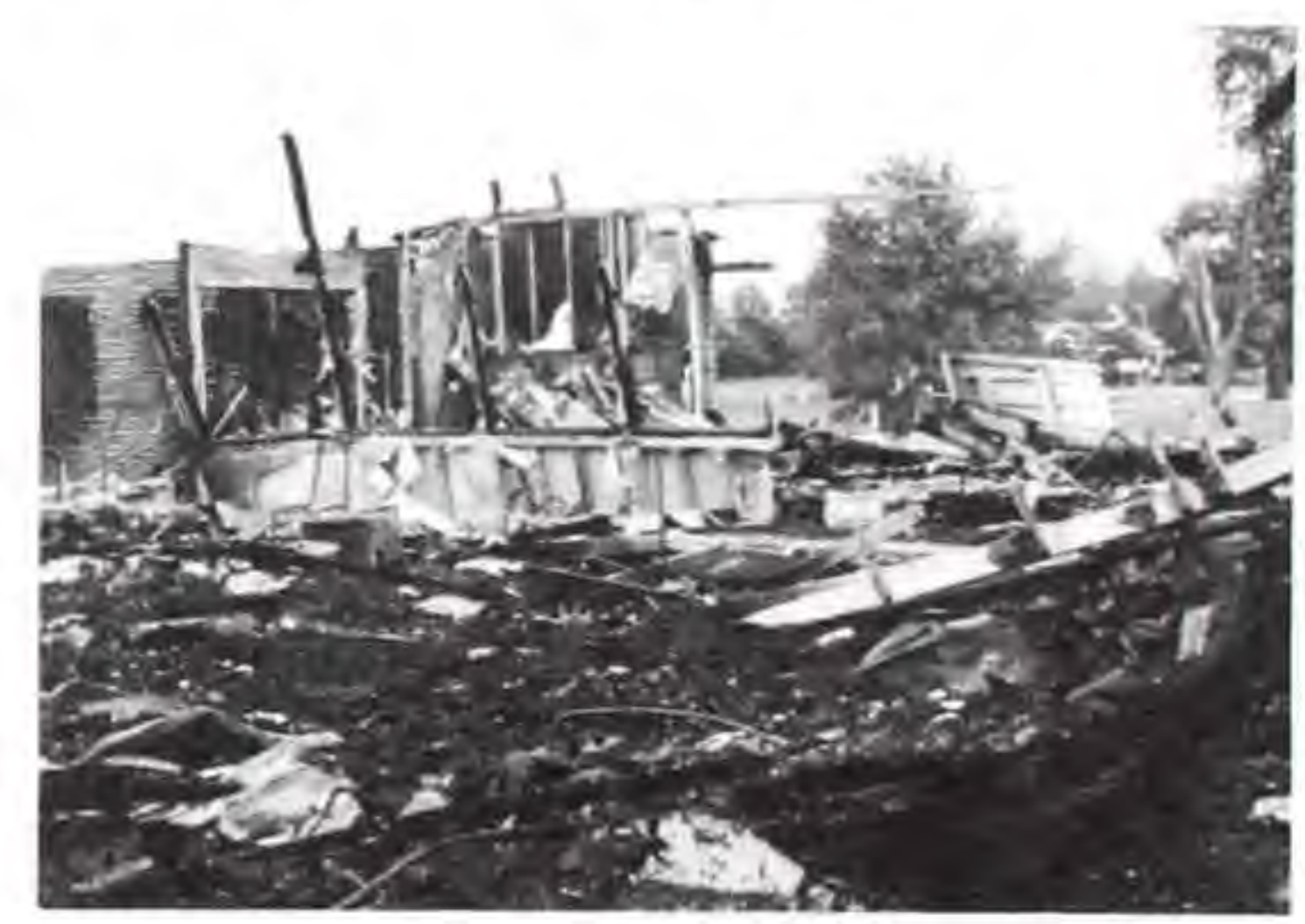

Remains of foyer

\section{Greenville Church Celebrates Milestones}

Faith Baptist is celebrating two impor$P$ tant milestones this September: its 40th anniversary as a church and the 20th year for the ministry of Faith Christian School. The church began in 1958 with Harold Green as pastor. Since then Faith Baptist has had only four other pastors: Joseph Godwin, Sr., Lloyd Learned, Joseph Godwin, Jr., and its present pastor, Max McCullough. Faith Christian School began in 1979 with 52 students and 5 teachers in grades K-7. Each year a grade was added, and in 1985 Faith Christian held its first commencement with 13 graduates. Including the recent class of 1998, 105 students have been awarded diplomas.

Former pastors and administrators joined the congregation on September 1920 for activities featuring an open house, hog roast, speaker Don Bartlette of "Macaroni At Midnight" and a Sunday worship celebration. 


\section{Graduation Day For Hope Chapel Baptist}

$\mathrm{O}$ July 26, after approximately three years of church planting efforts, Earl and Marilyn Shaffer rejoiced to see the Hope Chapel Baptist Church graduate from mission status to a self-supporting independent church. In the morning service Todd Bailey was installed as pastor of Hope Chapel. Todd and his wife, Melanie, sensing a call to church planting, have been working with the Shaffers for the past nine months. Earlier in July, as preparation for their independent status, the church had unanimously called Todd to be their pastor. As part of the service Norm Nicklas of ABWE gave a charge to the church and Eari Shaffer gave the charge to Todd. Several members of the Piqua church then gave symbolic gifts to Todd to represent his new role as pastor, including a towel for service and a Bible for preaching the Word. The women of the church provided a noon meal for everyone attending.

During the afternoon graduation service, many church members gave

\section{DAVE SAYS...}

Thanks! To the leadership team of Cedar Hill Baptist Church in Cleveland Heights for hosting our first leadership team gathering. You readily provided the atmosphere and delicious food, and happily participated in our agenda of games and introductions. Pat and I feel we know you and your church a lot better because of your willingness to open yourselves up to us. Allow us to commend your people for their long years of faithful leadership in our Ohio fellowship, for their outreach to nearby university students, including internationals, for your acceptance of all peoples as one in your body of believers. It was beautiful to see. Thank you for your help in moving us toward our goal of getting to know our churches and people across the state of Ohio.

We look forward to meeting all our leadership teams by October 1999. If we have not contacted you by our 1998 October meeting in Rootstown, feel free to suggest a couple dates to us by e-mail: WarrenOARBC@juno.com. testimonies as to how the ministry of the church has contributed to their salvation or growth as a believer. Pastor Jeff Willetts of Calvary Baptist, Bellefontaine, gave an instructive message on how God works in the transfer of leadership from one man to another, using the example of Moses and Joshua. The deacons of the church presented plaques and certificates to the many churches who had helped the Piqua church in some way. Messengers from these churches had come from as far as Portsmouth and Toledo. Many remarked how beautiful it was to see the love and support of these faithful brethren and the gracious transfer of leadership.

Welcome, Todd and Melanie, to our Ohio Association of Regular Baptist Churches. Our prayers go with you, Earl and Marilyn, as you wait on the Lord for further direction in your church planting efforts in Ohio.

\section{West African Missionaries In Glory}

$\mathrm{O}$ August 12, Baptist MidMissions missionaries to Ghana, West Africa, John Hayes and Sara Hayes, were struck and killed by a semi-trailer. The brother and sister were enroute to the airport with their father, Rev. Robert Hayes, of Milford, Ohio, who had been visiting them in Techiman, when the accident occurred. Reports are that Robert and Sara died instantly, and John shortly thereafter.

The funerals for all three were held at the First Baptist Church in Milford, home church of Robert and his wife, Alice, on August 21. John leaves his wife, June (Juleen) and three children: Michaela, David and Rachelle. Sara served God as a single missionary.

Dr. Evan Gough, field administrator for BMM, asks prayer for June and the children, Alice (Robert's wife), coworkers on the field in Ghana, and the national believers. In response to a question about finances, he noted that the cost to return the bodies to the States was $\$ 6,000$ each, in addition to flight expenses for June and the children. Gifts can be sent to John Hayes' account at BMM
Baptist Children's Home \& Family Ministry

Providing Christian Homes for needy children.

Ohio Office (937) 322-0006 Charles Monroe, Ohio Director

Professional comsulting and sales for your financial and insurance needs

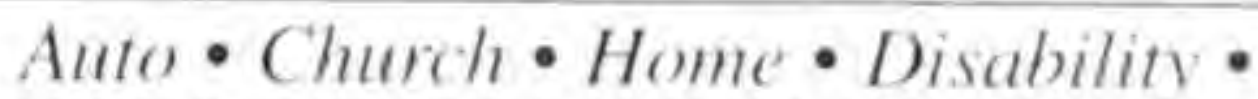
Life $\bullet$ Business $\cdot$ Annuities

PHELPS FINANCIAL SERVICES, INC.

Dorr R. Phelps, GP, CFP, RFP, LUTCF 659-H Park Meadows Drive

Westerville, Ohio 43081

PHONE: 614-899-6000

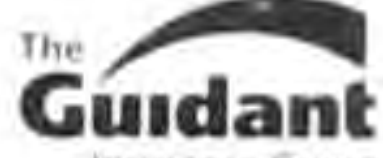

FAX: 614-899-6022

Buses \& Vans For Sale

15-84 passenger vehicles available

Buy quality for less at

7320 Transportation Equip. Sales Corp.

6401 Seaman Rd. Oregon, $\mathrm{OH} 43618$ $419-836-2835$

Toll-free nationwide 1-800-227-3572 "Big church discounts" ask for Bud Graham

Evangelism! Fun! Hockey! Bowling! Pizza \& Pop!

WORD OF LIFE SUPISRBOWL!!!!

Nov. 13, 199)

Cleveland Lumberjacks Cecil Cairns 440-355-5687

Cincinnati Cyclones (plus skating) Ken Dady 937-592-2358

Nov, 20,1998

Columbus Chill (plus skating) Ken Dady 937-592-2358 KJDADYSR@aol.com 


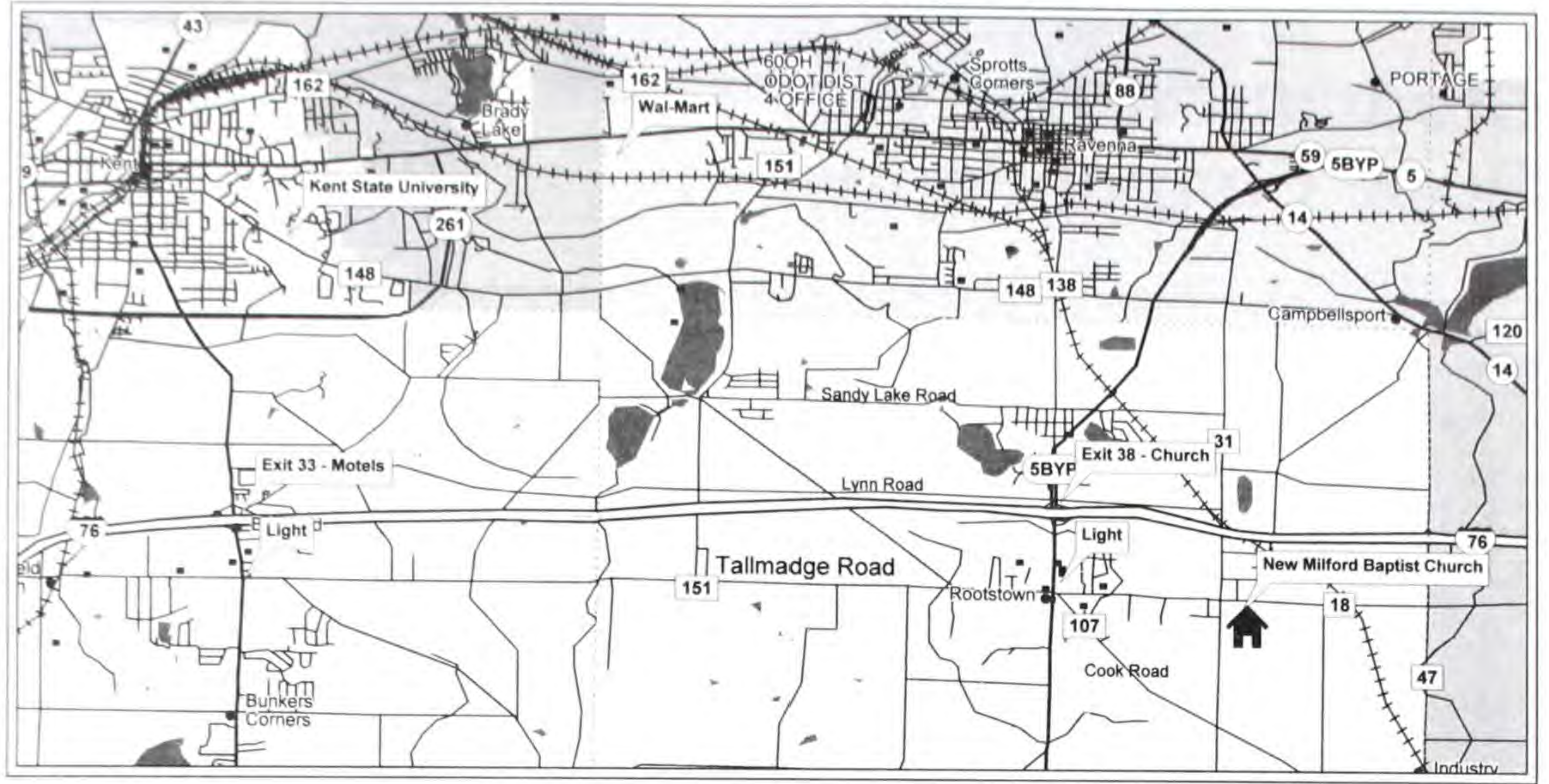

\section{How To Get To New Milford Baptist Church}

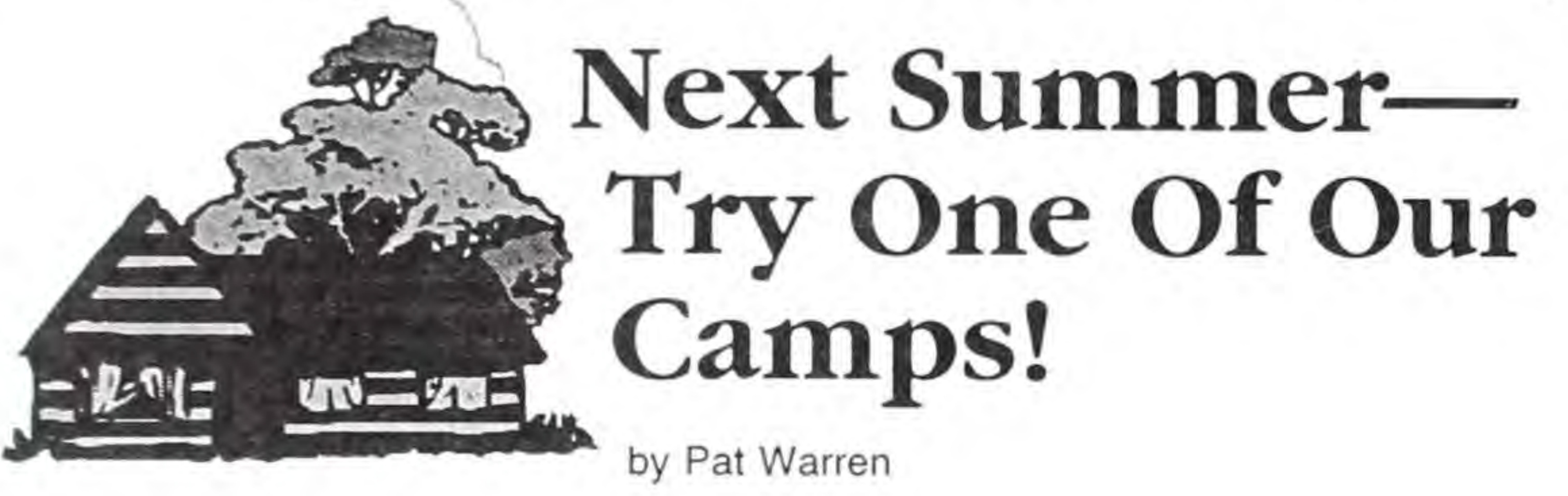

$\mathrm{H}$ as someone in your family been involved in a Christian camp this summer? Can you measure the benefits? It has been our privilege to use our summers to be involved in camp ministries in several of our neighboring states, as well as in Ohio, ever since the Lord called us into teaching 22 years ago. We in Ohio are blessed by having three camps approved by our OARBC: Patmos, Skyview and Scioto, as well as one operated for Baptist Mid-Missions, Shalom Lake. We have personally enjoyed the ministry of each over the years.

This summer our paths led us to Patmos for a family camp, where we "Clambered Through Colossians." No sooner had the boat from Marblehead left the dock than we began to relax. The breeze in our hair and the lap of the waves against the boat began to move us into a sense of appreciation for our God and for His creation, as well as His work in our lives. Perhaps you felt the same way as you drove into Amish country or rode a horse at Skyview, or rambled over the bridge into Scioto Hills or Shalom Lake.
We often tell folk, stop to enjoy this time out and away from responsibilities at home and at work. Look into the Scriptures, and listen to the inaudible voice of God as He speaks to you through His creation and His Word.

Each of these camps reaches out to children, teens and families in a unique way. Each one seeks to bring the gospel to unsaved and provide milk and meat to grow on for believers. We thank the Lord for these camps. Use them! We say this, not because they need us to drum up business, for most require early reservations to handle those who already want to come. We met several families this summer who used camp for a family reunion. Extended families across generations enjoyed the ministry of the Word together, as well as afternoons filled with a variety of activities.

Remember that all but the island camp of Patmos also offer fall, winter and spring retreats for a variety of groups. Check their schedules. Beauty is in the eye of the beholder, so try out the camp that fits your style of relaxation.

\section{Amstutz New Shepherds President}

$\mathrm{O}$ n September 1, Shepherds Home welcomed Rev. William J. Amstutz as its new president. Shepherds is a Christian residential care facility providing Compassionate Care to nearly 180 mentally disabled adults. Bill and his wife, Nancy, come to Union Grove from Bethel Baptist Church in Cherry Hill, New Jersey, where he served in education and counseling ministries. A graduate of Cedarville College and Grand Rapids Baptist Seminary, he is currently working on his Doctorate from Biblical Seminary in Hatfield, Pennsylvania.

"It is a privilege to be called to this great ministry, and I believe that God has wonderful things in store for Shepherds," says Amstutz. "I am dedicated to maintaining Shepherds high standards and even expanding our capacity to serve more residents as God allows." 